\title{
Transforming growth factor- $\beta 3$ intron 5 polymorphism as a screening marker for non-syndromic cleft lip with or without cleft palate
}

\author{
KORKUT ULUCAN $^{1}$, NAZLI BAYRAKTAR ${ }^{1}$, EMINE PARMAKSIZ $^{1}$, ARZU AKCAY $^{2}$ and AHMET ILTER GÜNEY ${ }^{3}$ \\ ${ }^{1}$ Department of Molecular Biology and Genetics, Faculty of Engineering and Natural Sciences, Üsküdar University; \\ ${ }^{2}$ Department of Pediatric Hematology and Oncology, Kanuni Sultan Suleyman Education and Research Hospital; \\ ${ }^{3}$ Department of Medical Genetics, Faculty of Medicine, Marmara University, Istanbul, Turkey
}

Received May 23, 2012; Accepted September 21, 2012

DOI: $10.3892 / \mathrm{mmr} .2012 .1097$

\begin{abstract}
In this study, we evaluated the effect of transforming growth factor $\beta 3$ intron 5 position $+104 \mathrm{~A} \rightarrow \mathrm{G}$ (TGF- $\beta 3$ IVS5+104AG) transition in patients with a non-syndromic cleft lip with or without cleft palate (NSCL/P). A total of 68 patients and 114 controls were recruited for the study. A genotyping procedure was carried out using the PCR-RFLP method. For statistical analysis, the Chi-square test was used to compare data between the patient and control groups. The frequencies of the AA, AG and GG genotypes were 24,29 and $47 \%$, respectively, for the patients and 54,36 and $10 \%$, respectively, for the control group. The GG genotype and G allele were significantly different in the patient group compared with the control ( $\mathrm{p}=0.0001)$. We conclude that $S f a \mathrm{~N} 1$ polymorphism in TGF- $\beta 3$ may be a good screening marker for the prediction of NSCL/P in patients. However, more studies with extended sample numbers should be carried out to clarify the effect of the examined gene region on NSCL/P.
\end{abstract}

\section{Introduction}

Non-syndromic cleft lip with or without cleft palate (NSCL/P) is one of the most common congenital malformations worldwide and has a prevalence of $1 / 700$ live births (1). NSCL/P is so-called since individuals with the condition do not exhibit any other anomalies, and it is caused by environmental factors and multiple genes that interact with the environmental factors or with each other. Therefore, this condition is accepted to

Correspondence to: Dr Korkut Ulucan, Department of Molecular Biology and Genetics, Faculty of Engineering and Natural Sciences, Üsküdar University, İcadiye Mahallesi, Bağlarbaşı Caddesi, No. 63 Uskudar, Istanbul 34675, Turkey

E-mail: korkutulucan@hotmail.com

Key words: transforming growth factor $\beta$, non-syndromic cleft lip with or without palate, polymorphism, screening, patients be multi-factorial (2). The exact etiology of the condition is unknown. There are several genes or gene fragments associated with NSCL/P, however, the results are conflicting when examined in different populations. It is difficult to associate the condition with a single gene having a clearly defined relationship due to its multi-factorial nature.

Animal studies provide a variety of information concerning the functions of candidate genes in the pathogenesis of congenital anomalies. Previous findings showed that signaling pathways including the transforming growth factor $\beta$ (TGF- $\beta 3$ ) are significant in palate development (3). Clefting anomalies arise from dysregulation of the shelf elevation, attachment and fusion of mesenchymal and epithelial cells. During shelf elevation, TGF- $\beta 3$ regulates the proliferation of mesenchymal cells and changes in the extracellular matrix, and also regulates the shelf attachment of the epithelium by cell differentiation. During the fusion process, TGF- $\beta 3$ regulates epithelium-mesenchymal transformation (3). Homozygous TGF- $\beta 3$-null transgenic mice exhibited cleft palate (4) and when mutation analyses of this gene were extended to clefting in humans, the results of these studies indicated the involvement of the TGF- $\beta 3$ gene in clefting (5).

Recently, Sato et al reported an association between TGF- $\beta 3$ and cleft lip and palate in the Japanese population (6). Polymorphisms in exons 2 and 5 of the TGF- $\beta 3$ gene are reportedly associated with cleft palate (7). Kim et al examined the TGF- $\beta 3$ gene in Korean NSCL/P patients and controls and identified statistically significant differences in intron 5 of the gene, which they concluded to be a good marker for NSCL/P screening (8). CA nucleotide repeats that are specific to the TGF- $\beta 3$ gene were examined in the Indian population and a significant difference was observed between the NSCL/P and control groups (9). The same CA repeats in the TGF- $\beta 3$ gene were analyzed in the Chinese population and researchers suggested the gene as an important genetic risk factor in Chinese children (10). Reutter et al reported a parent-of-origin effect of the T allele, at rs2300607 of the gene, in individuals of central European origin. The children who inherited the $\mathrm{T}$ allele from their mothers demonstrated a decreased risk compared with those who inherited the same allele from their fathers (11). However, Lidral et al did not find any association 
between the TGF- $\beta 3$ gene and cleft lip and palate in patients in the Philippines (12).

Previous studies have shown that there are variations in the TGF- $\beta 3$ gene and differences in study protocols in various populations (7,9-11). More extended studies in different populations are required to understand the exact role of the TGF- $\beta 3$ gene in NSCL/P. At present, there is little epidemiological genetic information concerning cleft-related genes in the Turkish population. In this study, we assessed the association between the TGF- $\beta 3$ IVS5+104AG variation and NSCL/P in Turkish patients.

\section{Patients and methods}

Subjects. A total of $68 \mathrm{NSCL} / \mathrm{P}$ patients with Turkish ancestry were enrolled in this study. Information concerning the patients and their parents was obtained during their first visits to Marmara University, Faculty of Dentistry and Sisli Etfal Education and Research Hospital. A total of 114 healthy subjects without any genetically transmitted disease in their families and first-degree relatives were recruited as a control group for the study. The patients were examined for clefting status and any other anomaly that may be a criterion for any other syndrome. The study procedure was in accordance with the principles of the Declaration of Helsinki II and all subjects provided written informed consent prior to enrollment.

DNA sample collection. DNA was isolated from $2 \mathrm{ml}$ peripheral blood using the High Pure PCR Template Preparation kit (Roche Diagnostics, Mannheim, Germany) and from buccal cells using the Quick Extract DNA Extraction solution (Epicentre, Madison, WI, USA) from those individuals from whom blood samples could not be obtained. In the two procedures, the instructions of the manufacturers were followed.

TGF- $\beta 3$ genotyping. Determination of the TGF- $\beta 3$ gene IVS $5+104 \mathrm{~A} \rightarrow \mathrm{G}$ transition was completed as previously reported (8), with small modifications. Briefly, sense primer 5'-GAGCAGGAGATTGTCACTTTC-3' and antisense primer 5'-TGACCAAGCATCTCCAATC-3' were used. PCR reactions were carried out in a volume of $50 \mu \mathrm{l}$ containing $5 \mu \mathrm{l}$ genomic DNA, $5 \mu \mathrm{l}$ 10X Taq buffer, $3 \mu 125 \mathrm{mM} \mathrm{MgCl}_{2}, 1 \mu \mathrm{l}$, $0.2 \mathrm{mM}$ dNTP, $2 \mu \mathrm{l}, 1 \mu \mathrm{M}$ primers and $0.5 \mu \mathrm{l}, 2$ units Taq polymerase (Fermentas, Vilnius, Lithuania). The reaction was completed over 34 cycles and comprised predenaturation at $94^{\circ} \mathrm{C}$ for $5 \mathrm{~min}$, denaturation at $94^{\circ} \mathrm{C}$ for $45 \mathrm{sec}$, annealing at $51^{\circ} \mathrm{C}$ for $20 \mathrm{sec}$, extension at $72^{\circ} \mathrm{C}$ for $45 \mathrm{sec}$ and a final extension at $72^{\circ} \mathrm{C}$ for $7 \mathrm{~min}$. In order to determine the allelic types, $S f a \mathrm{~N} 1$ digestion was carried out. For the AA genotype, the amplicon was digested to form a 506-bp fragment; for the GG genotype, the amplicon was digested into 331- and 194-bp fragments whereas the heterozygous AG genotype gave rise to three bands, of 506, 331 and $194 \mathrm{bp}$.

Statisical analysis. Statistical analysis was performed using SPSS for Windows version 20.0 (SPSS inc., Chicago, IL, USA). The significance in the statistical analyses between the patient and control groups was assessed using the Chi-square test. $p<0.05$ was considered to represent a statistically significant result.
Table I. Genotype and allelic determination of patients and controls.

\begin{tabular}{|c|c|c|c|c|c|}
\hline \multirow[t]{2}{*}{ Individuals } & \multicolumn{3}{|c|}{ Genotype } & \multicolumn{2}{|c|}{ Allele type } \\
\hline & AA & $\mathrm{AG}$ & GG & G & A \\
\hline \multicolumn{6}{|l|}{ Patient group } \\
\hline $\begin{array}{l}\text { No. of patients } \\
(\mathrm{n}=68)\end{array}$ & 16.0 & 20.0 & 32.0 & 52.0 & 84.0 \\
\hline Percentage $(\%)$ & 23.5 & 29.4 & 47.1 & 38.2 & 61.8 \\
\hline \multicolumn{6}{|l|}{ Control group } \\
\hline $\begin{array}{l}\text { No. of controls } \\
(\mathrm{n}=114)\end{array}$ & 62.0 & 41.0 & 11.0 & 165 & 63.0 \\
\hline Percentage $(\%)$ & 54.4 & 36.0 & 9.60 & 72.4 & 276 \\
\hline
\end{tabular}

\section{Results}

A total of 68 patients and 114 controls were genotyped in the present study. In the patient group, 16 patients had the AA genotype, 20 the AG genotype and 32 the GG genotype for the examined polymorphism. The respective frequencies of the AA, AG and GG genotypes of the patients were 24, 29 and $47 \%$. In the control group, 62 individuals had the AA genotype, 36 the AG genotype and 11 the GG genotype. The frequencies of the AA, AG and GG genotypes were 54,36 and $10 \%$, respectively. The GG genotype was statistically associated with the anomaly compared with the controls $(\mathrm{p}=0.0001)$. When the AA genotype was used as the reference group, the $G$ allele frequency was statistically higher in the patient group than in the controls ( $\mathrm{p}=0.0001)$. All genotype and allele numbers and frequencies are summarized in Table I.

\section{Discussion}

The TGF- $\beta 3$ gene, located at $14 q 24$, encodes a member of the TGF- $\beta$ super family of proteins. These proteins have variety of functions, including cell differentiation, proliferation, motility, apoptosis and homeostasis (13). Palatogenesis involves palatal shelf formation, growth and elevation, fusion of the elevated paired shelves and medial edge epithelium (MEE) disappearance to allow mesenchymal convergence (14). In these processes, the TGF- $\beta 3$ gene plays a crucial role, and is highly expressed in the epithelial tissue of the medial edge of the palatal shelves. In order to clarify the role of TGF- $\beta 3$ in the onset of NSCL/P, epidemiological studies have been carried out in a number of countries and various ethnic populations.

Previously, it has been demonstrated that TGF- $\beta 3$ null transgenic mice exhibited cleft palates with no related craniofacial anomalies (4). To date, certain reports have suggested a correlation between polymorphisms in the TGF- $\beta 3$ gene and clefts $(9,15)$. Saleem et al examined the allelic forms of the TGF- $\beta 3$ gene according to CA repeats and reported that there is a significant difference in the number of CA repeats between the case and control groups in the Indian subpopulation (9). Guo et al analyzed the association between C641A and G15572- polymorphisms of the TGF- $\beta 3$ gene and maternal 
exposures during pregnancy, including maternal smoking and multivitamin use (16). The authors found that C641A polymorphism does not have an effect in cleft formation as a single locus, although it has an effect when it interacts with maternal passive smoking. Vieira et al investigated the transmission distortion of the TGF- $\beta 3$ gene in 217 South American children from their mothers. The authors used likelihood ratio test analysis and revealed that patients with a cleft palate were associated with TGF- $\beta 3$ gene mutations (17).

Coding and non-coding regions of the gene, the latter as a marker, have been analyzed and associated with the condition. Lidral et al demonstrated linkage disequilibrium between CL/P and the TGF- $\beta 3$ X5.1 variant, which is located at position -24 of intron 4 , by a transmission/disequilibrium test (TDT) (12). The authors also reported a cleft palate risk with the same allele in addition to maternal smoking. Romitti et al examined the TGF- $\beta 3$ gene CA2, X5.1 and 5-UTR variants and found that alcohol consumption, related to the examined alleles, increased the risk of clefts (15). Ichikawa et al analyzed TGF- $\beta 3$ in 112 CL/P cases and 192 controls and found a significant association between intron 1 , at position +5321 of the gene, and CL/P patients (18).

The expression levels of the examined gene products are also important for identifying the roles of the candidate factors. TGF- $\beta 3$ expression has been found to be impaired in the ectodermal derivatives of non-syndromic cleft patients, suggesting the importance of TGF- $\beta 3$ action in proper palatogenesis (19).

Kim et al analyzed the TGF- $\beta 3$ gene in 28 Korean patients and 41 controls. They detected no mutation in the coding regions but found an SNP in intron 5, at position +104 , relative to the exon 5 /intron 5 boundary (8). This $A \rightarrow G$ variation creates a digestion site for the $S f a \mathrm{~N} 1$ restriction enzyme. They found that a $\mathrm{G}$ allele and $\mathrm{GG}$ genotype were risk factors for NSCL/P in Korean patients. The authors also suggested that the newly introduced polymorphic site should be analyzed in different populations to determine the contribution of population heterogeneity to the result.

The results of our case-control study are in agreement with those of Kim et al (8). In the present study, we analyzed 68 NSCL/P and 114 control cases, all with Turkish ancestry, for the $S f a \mathrm{~N} 1$ polymorphism. The AA genotype was accepted as a reference and the GG genotype showed a significant difference in the NSCL/P cases compared with the controls. Additionally, when we examined the allelic distribution, the $G$ allele was highly associated with the anomaly. These results revealed that this region of the gene may be a good screening marker for $\mathrm{NSCL} / \mathrm{P}$. The molecular effect of this variation is unknown and is a subject for further study. As this polymorphism lies near to the exon 5/intron 5 boundary, it may have an effect on splicing processes. Alternatively, this variation may be linked with another gene that is involved in the pathology of NSCL/P.

This is the first study of Turkish cases of NSCL/P and the $S f a N 1$ site of the TGF- $\beta 3$ gene intron 5 region. The major limitation of this study was the low numbers of case and control subjects. The results from this study are inadequate for us to make an informative comment on the examined region and the role of that region in the onset of NSCL/P in the Turkish population. In order to make a precise conclusion concerning the condition and the TGF- $\beta 3$ gene intron 5 region, a metaanalysis of the SNP between case and controls in the Turkish population, and in different populations, must be performed. In addition, the examination of whole genes and the determination of the allelic types according to CA repeats in case-parent triads is likely to be the focus of our further studies.

\section{References}

1. Hashmi SS, Waller DK, Langlois P, Canfield M and Hecht JT: Prevalence of nonsyndromic oral clefts in Texas: 1995-1999. Am J Med Genet A 134: 368-372, 2005.

2. Lidral AC and Moreno LM: Progress toward discerning the genetics of cleft lip. Curr Opin Pediatr 17: 731-739, 2005.

3. Proetzel G, Pawlowski SA, Wiles MV, Yin M, Boivin GP, Howles PN, Ding J, Ferguson MW and Doetschman T: Transforming growth factor-beta 3 is required for secondary palate fusion. Nat Genet 11: 409-414, 1995.

4. Murray JC: Gene/environment causes of cleft lip and/or palate. Clin Genet 61: 248-256, 2002.

5. Iwata J, Parada C and Chai Y: The mechanism of TGF- $\beta$ signaling during palate development. Oral Dis 17: 733-744, 2011.

6. Sato F, Natsume N, Machido J, Suzuki S and Kawai T: Association between transforming growth factor beta 3 and cleft lip and/or palate in the Japanese population. Plast Reconstr Surg 107: 1909-1910, 2011.

7. Maestri NE, Beaty TH, Hetmanski J, Smith EA, McIntosh I, Wyszynski DF, Liang KY, Dufy DL and VanderKolk C: Application of transmission disequilibrium tests to nonsyndromic oral clefts: including candidates genes and environmental exposures in the models. Am J Med Genet 73: 337-344, 1997.

8. Kim MH, Kim HJ, Choi JY and Nahm DS: Transforming growth factor-beta 3 gene SfaN1 polymorphism in Korean nonsyndromic cleft lip and palate patients. J Biochem Mol Biol 36: 533-537, 2003.

9. Saleem S, Rajendran R, Moinak B, Anna J and Pramod BJ: Evidence for transforming growth factor-beta 3 gene polymorphism in non-syndromic cleft lip and palate patients from Indian sub-continent. Med Oral Patol Oral Cir Bucal 17: e197-e200, 2012.

10. Zhu J, Hao L, Li S, Bailey LB, Tian Y and Li Z: MTHFR, TGFB3, and TGFA polymorphisms and their association with the risk of non-syndromic cleft lip and cleft palate in China. Am J Med Genet A 152A: 291-298, 2010.

11. Reutter H, Birnbaum S, Mende M, Lauster C, Schmidt G Henschke H, Saffar M, Martini M, Lauster R, Schiefke F, et al: TGFB3 displays parent-of-origin effects among central Europeans with nonsyndromic cleft lip and palate. J Hum Genet 53: 656-661, 2008 .

12. Lidral AC, Murray JC, Buetow KH, Basart AM, Schearer H, Shiang R, Naval A, Layda E, Magee K and Magee W: Studies of the candidate genes TGFB2, MSX1, TGFA, and TGFB3 in the etiology of cleft lip and palate in the Philippines. Cleft Palate Craniofac J 34: 1-6, 1997.

13. Gatza CE, Oh SY and Blobe GC: Roles for the type III TGF-beta receptor in human cancer. Cell Signal 22: 1163-1174, 2010.

14. Ferguson MW: Palate development. Development 103 (Suppl): 41-60, 1998.

15. Romitti PA, Lidral AC, Munger RG, Daack-Hirsch S, Burns TL and Murray JC: Candidate genes for nonsyndromic cleft lip and palate and maternal cigarette smoking and alcohol consumption: evaluation of genotype-environment interactions from a population-based case-control study of orofacial clefts. Teratology 59: 39-50, 1999.

16. Guo Z, Huang C, Ding K, Lin J and Gong B: Transforming growth factor beta-3 and environmental factors and cleft lip with/without cleft palate. DNA Cell Biol 29: 375-380, 2010.

17. Vieira AR, Orioli IM, Castilla EE, Cooper ME, Marazita ML and Murray JC: MSX1 and TGFB3 contribute to clefting in South America. J Dent Res 82: 289-292, 2003.

18. Ichikawa E, Watanabe A, Nakano Y, Akita S, Hirano A, Kinoshita A, Kondo S, Kishino T, Uchiyama T, Nikawa N and Yoshiura K: PAX9 and TGFB3 are linked to susceptibility to nonsyndromic cleft lip with or without cleft palate in the Japanese: population-based and family-based candidate gene analyses. J Hum Genet 51: 38-46, 2006.

19. Rullo R, Gombos F, Ferraraccio F, Farina A, Morano D, Festa VM, Guida L, Martinelli M, Scapoli L, Pezzetti F and Carinci F: TGF 33 expression in non-syndromic orofacial clefts. Int J Pediatr Otorhinolaryngol 70: 1759-1764, 2006. 